University at Albany, State University of New York

Scholars Archive

2-2019

\title{
Hurricane Maria's Aftermath: Redefining Puerto Rico's Colonial Status
}

Pedro Caban

University at Albany, State University of New York, pcaban@albany.edu

Follow this and additional works at: https://scholarsarchive.library.albany.edu/lacs_fac_scholar

Part of the Latin American Studies Commons, Politics and Social Change Commons, and the Race and Ethnicity Commons

\section{Recommended Citation}

Caban, Pedro, "Hurricane Maria's Aftermath: Redefining Puerto Rico's Colonial Status" (2019). Latin American, Caribbean, and U.S. Latino Studies Faculty Scholarship. 34.

https://scholarsarchive.library.albany.edu/lacs_fac_scholar/34

This Article is brought to you for free and open access by the Latin American, Caribbean, and U.S. Latino Studies at Scholars Archive. It has been accepted for inclusion in Latin American, Caribbean, and U.S. Latino Studies Faculty Scholarship by an authorized administrator of Scholars Archive. For more information, please contact scholarsarchive@albany.edu. 


\title{
CURRENT HISTORY
}

\author{
February 2019
}

\author{
"Hurricane Maria laid bare the painful reality that Puerto Rico is an inconsequential
} American territory inhabited by second-class US citizens."

\section{Hurricane Maria's Aftermath: Redefining Puerto Rico's Colonial Status?}

\author{
PEDRO CABÁN
}

$\mathrm{H}$ urricane Maria was a singular event in Puerto Rico's history. The storm struck on September 20, 2017, and left unparalleled devastation in its wake. At least 2,975 people lost their lives in the storm and its aftermath. Property damage and lost economic output exceeded $\$ 95$ billion. The Trump administration's emergency and recovery response was widely criticized as inadequate and mismanaged. Maria shattered many Puerto Ricans' belief that the United States would never allow a humanitarian crisis to imperil the lives of its citizens.

The desultory response to the disaster has revived a lingering debate over the viability of Puerto Rico's commonwealth status. It was a sobering reminder that Puerto Rico is not equal to the member states of the union. In fact, nothing has changed since 1901, when the Supreme Court ruled that Puerto Rico was merely "a territory appurtenant and belonging to the United States, but not part of the United States." Hurricane Maria laid bare the painful reality that Puerto Rico is an inconsequential American territory inhabited by second-class US citizens.

From its seizure by the United States in 1898 in the Spanish-American War until the dissolution of the Soviet Union in 1991, Puerto Rico was a valuable strategic asset and a highly profitable investment site for US corporate capital. However, during the past quarter-century Puerto Rico has seen its status as America's shining star in the Caribbean slowly dim. The US Navy shuttered its sprawling

PEDRO CABÁN is a professor and chair of the department of Latin American, Caribbean, and US Latino Studies at the University at Albany, State University of New York. base there over two decades ago after belatedly acknowledging that it had become an anachronistic military asset unsuitable for training for modern warfare. Similarly, multinational corporations that once extracted great profits from Puerto Rico have essentially abandoned it.

Globalization and a reconceptualization of US strategic interests in a transformed geopolitical environment have had a devastating impact on the once prized territory. Through no fault of its own, Puerto Rico is no longer regarded as an advantageous possession by the United States. This change in Puerto Rico's status in the American empire ultimately made the island particularly vulnerable to Maria's destructive force.

\section{ECONOMIC SHOCKS}

Hurricane Maria was the culmination of a series of shocks that hit Puerto Rico over the past decade and a half-a ruinous trifecta of economic crises. The first was set in motion in 1996, when President Bill Clinton signed legislation phasing out Section 936, a provision of the US tax code that granted an exemption for corporate income from operations in Puerto Rico. When the tax incentive expired in 2006, corporations abandoned the island and manufacturing employment plummeted.

In 2004, the Navy closed the sprawling Roosevelt Roads military complex. Thousands of jobs were lost, and the millions of dollars the Pentagon spent on construction and base operations stopped flowing into the local economy. Demilitarization aggravated the already precarious economic situation caused by the termination of Section 936 . Both of these developments propelled Puerto Rico 
into a depression starting in 2006. For 11 of the past 12 years, the island has endured negative growth rates.

With tax revenue depleted by the depression, successive Puerto Rican governments increased their reliance on municipal bonds to balance the budget and pay for essential public services, even as they sought to control costs by imposing austerity. Out-migration increased markedly as the economic crisis wore on, particularly among skilled and educated workers. The exodus further reduced the tax base.

As investment capital dried up, government officials worked with Wall Street financial firms to aggressively market bond issues. Puerto Rico quickly amassed a staggering debt, which tripled from $\$ 25$ billion in 2000 to $\$ 74$ billion by 2016 . The government also had unfunded public-employee pension obligations of nearly $\$ 50$ billion. Almost half the bond debt was acquired during the tenures of governors Luis Fortuño (2009-13) of the New Progressive Party, which advocates statehood, and Alejandro García Padilla (2013-17) of the Popular Democratic Party, which favors maintaining commonwealth status.

On June 29, 2015, García Padilla shocked the bond market when he announced that Puerto Rico lacked the financial resources to meet its debt obligations. In April 2016, he warned that the island's fiscal situation was "more dire than at any other point in its history" and it might be forced to choose between honoring its commitments to bondholders and continuing to provide residents with essential services. Congress acted quicklyto protect the bondholders.

On July 1, 2016, President Barack Obama signed into law the Puerto Rico Oversight, Management, and Economic Stability Act (PROMESA). The act established the Financial Oversight and Management Board (FOMB), known in Puerto Rico as la junta. The law gives the board, whose members are appointed by Congress and the president, broad powers over the local government's fiscal and economic policies.

The FOMB has the authority to order the government to implement its recommendations. It can block the enforcement or execution of certain contracts, executive orders, and "any territorial law or regulation that is inconsistent with [PROMESA] or fiscal reform plans." The junta's seizure of the Puer- to Rican government's fiscal powers was the third shock that befell the island before Hurricane Maria.

Paul Ryan, then the speaker of the US House of Representatives and one of the architects of PROMESA, justified the legislation by asserting that Puerto Rico "paved the way for this disaster with decades of irresponsible policies like overspending and fiscal mismanagement."

Likewise, President Donald Trump has regularly disparaged Puerto Rican politicians as incompetent and corrupt, a theme he has returned to since the hurricane. On October 23, 2018, he claimed that "inept politicians are trying to use ... disaster funding to pay off other obligations."

\section{ERODING INFRASTRUCTURE}

Puerto Ricans were stunned by the severity of the devastation that Hurricane Maria left in its wake. But the great loss of life and massive destruction cannot be explained solely by Maria's wrath. Puerto Rico was woefully unprepared to protect itself from the fearsome power of a Category 4 hurricane. Well before Maria, its physical and human infrastructure was in a state of severe disrepair. For over a decade, the government and public corporations curtailed spending for maintenance of critical systems, particularly the electrical grid.

In 2009, the Fortuño administration pushed through the draconian Special Act to Declare a State of Fiscal Emergency in an effort to reduce the mounting budget deficit and prevent further deterioration of its credit rating. The measure was Puerto Rico's first attempt to impose a severe neoliberal austerity program in order to shrink the state bureaucracy. Government funding was slashed by 20 percent. Tens of thousands of public employees were dismissed, wages were frozen, union contracts were suspended, and worker benefits were curtailed. Many Puerto Ricans took part in demonstrations against Fortuño's regressive policies.

García Padilla followed suit, cutting spending on physical infrastructure as well as the already stressed human infrastructure: education, health and hospitals, sanitation, and nutrition services. He increased the sales tax and imposed a new tax on services which had a disproportionate impact on the working and middle classes. About 50 percent of the revenue from these taxes was used to 
service the debt. The government also cut investments in roads, water-treatment facilities, public schools, and other critical infrastructure from $\$ 2.4$ billion in 2012 to $\$ 906$ million in 2017 . The university budget was slashed by 20 percent.

Although the combined Fortuño and García Padilla austerity measures failed to reduce the debt, they increased unemployment, income inequality, and poverty while reducing public services for the most vulnerable members of society. After years of systematically defunding its physical and human infrastructure, Puerto Rico was highly vulnerable to a catastrophic storm like Hurricane Maria.

\section{A COLONIAL ECONOMY}

On the surface, Puerto Rico may have appeared to be a modern Caribbean society that could withstand and recover quickly from a major hurricane. But Maria ripped off the thin veneer of modernity and exposed the fault lines in contemporary colonialism.

For over 120 years, Congress has denied Puerto Rico self-rule and the authority to control its political economy. Since Puerto Rico is prohibited by the United States from filing for relief under Chapter 9 of the federal bankruptcy code (which is intended for municipalities), it enacted its own bankrupcy law in 2014. The bondholders sued Puerto Rico, and the US Supreme Court sided with them in 2016, ruling that federal law superseded the Puerto Rican bankruptcy law. However, the PROMESA bill contains a provision (Title III) that allows the FOMB to file a petition for debt restructuring in federal court on behalf of Puerto Rico.

The limited fiscal autonomy that Congress had unofficially conferred in 1952 was stripped away by PROMESA. Since it is not sovereign, Puerto Rico cannot join the International Monetary Fund, enter into international treaties, or obtain emergency lending or development funds from multilateral lending institutions.

Because Puerto Rico has no voting member in the US Congress, the federal government enacts policies that literally have life-or-death consequences for Puerto Ricans without their consent. This form of colonialism has saddled Puerto Rico with an economy that is on life support, dependent on continuous infusions of American corporate capital and federal transfers.

In 1947, Puerto Rico initiated a successful "industrialization by invitation" development program, dubbed Operation Bootstrap, which attracted hundreds of US-owned factories to the island.
In order to sustain the confidence of investors, the Puerto Rican government had to prioritize corporate profitability. Acting through self-financed state-owned corporations, it established a modern infrastructure that offered private firms subsidized services vital to their operations.

Between 1947 and 1963, the island's annual GDP growth rate was 6.6 percent, which exceeded that of the United States. The economy continued to grow rapidly over the next decade, increasing at an average annual rate of 7.7 percent from 1964 through 1973, and reaching an all-time high of 13.8 percent in 1971.

During the Cold War, Puerto Rico was portrayed as an "economic miracle" and used in a global ideological campaign against communism and the nonaligned movement. The territory was held up as proof positive that small, labor-abundant, open economies could develop industrially under American tutelage. However, as the historian Gordon Lewis has pointed out, Puerto Rico's industrialization was the result of "artificial advantages" that flowed from its colonial status.

Its growth was possible because corporations investing in Puerto Rico were beneficiaries of preferential federal tax legislation, as well as low wages, industrial subsidies and incentives, and other inducements including tax exemptions granted by the Puerto Rican government. An array of other "artificial advantages" accruing to Puerto Rico because of its status as a colony facilitated growth, such as the common currency and customs system, unrestricted emigration to the United States, and billions of dollars in federal transfers: Medicaid, Social Security, and veterans pensions, direct aid (such as nutrition assistance), and subsidies for the Puerto Rican administration's operations.

Unemployment was kept at tolerable levels because robust labor markets in the United States attracted Puerto Rican workers. The government sponsored this migration. During the "Great Migration" of 1950-60, 470,000 Puerto Ricans left the island.

However, the rapid pace of postwar economic growth could not be sustained. Growth plummeted to 1.7 percent annually during the 1973-77 recession. By the mid-1970s, Puerto Rico was no longer an internationally competitive site for American manufacturing capital. Many labor-intensive firms relocated to newly industrializing countries where they could enjoy higher profit margins thanks to much lower wages. 
The removal of surplus population through emigration, along with federal transfers and subsidies, prevented Puerto Rico's social fabric from unraveling and allowed local elites to maintain the fiction that they were effectively managing the economy. Yet it was not only successive local administrations that were reluctant to extricate the island from a flawed development model. The federal government was unwilling to grant Puerto Rico the autonomy it needed to formulate alternative approaches.

But Puerto Rico was developing into a political embarrassment for the United States. The increasing unemployment and poverty on the island, the growing exodus of Puerto Ricans, and heightened political agitation over economic and social inequalities revealed deep problems in the once valued colony. The New York Times commented in 1976 that the "heady days of 'Operation Bootstrap,' when Puerto Rico was hailed as a model for developing small countries, are definitely over."

During this period of economic decline and political tension, Congress enacted Section 936 in 1976 to promote investment by different industrial sectors. The provision induced capital-intensive companies to invest in Puerto Rico by allowing them to retain profits free of federal taxes. Manufacturers of electronics, medical devices, and particularly pharmaceuticals took advantage of the tax exemption and flocked to the island. However, these heavily capitalized firms had a marginal impact on manufacturing employment since they essentially replaced the more labor-intensive firms that had abandoned Puerto Rico.

In series of reports starting in 1978, the US Treasury Department concluded that the tax provision was depriving the federal government of billions of dollars in tax revenue, while the firms benefiting from the incentive failed to generate sufficient employment to justify their gains. Twenty years after Section 936 was enacted, Clinton ordered a 10-year phaseout of the law. Investments in manufacturing dwindled.

The termination of Section 936 signaled the beginning of the end of Puerto Rico's manufacturingbased economy and forced the government to rely on debt financing to generate the revenue it desperately needed to sustain its operations. But nonstop borrowing and subsequent defaults prompted the credit-rating agenices to steadily downgrade Puerto Rican bonds until the island government was locked out of the credit markets. Its economic fate would be decided by the FOMB.

\section{DRACONIAN DOWNSIZING}

In October 2018, more than a year after Maria, the FOMB released a fiscal plan to put Puerto Rico on the path to financial solvency. The junta will downsize the public bureaucracy, close and consolidate hospitals, privatize public corporations, eliminate worker-protection legislation, and make other changes that will transform Puerto Rico's economy and society.

According to the FOMB, "increasing labor force participation and job creation may be the single most important reform for long-term economic well-being in Puerto Rico." Law 80, which imposes penalties on employers that dismiss workers without cause, is anathema to the junta. To increase the workforce, the junta asserts that Puerto Rico will need to become an "at-will employment" jurisdiction.

The FOMB also maintains that generous social welfare benefits contribute to the low labor participation rate, since "working in the informal sector and collecting transfer benefits" can "result in higher effective income than working in the formal sector." Thus, the junta proposes welfare reforms that will reward "citizens who participate in the formal economy." The fiscal plan also calls for a 10-percent cut in the public pension system and a 30-percent cut in funding for public services.

The labor-market reforms proposed in this plan are so unpopular that the legislature, controlled by the pro-statehood party, has refused to approve enabling legislation. However, in October the FOMB certified the fiscal plan over the opposition of Governor Ricardo Rosello. "This is not a fiscal plan for economic development, this is an austerity plan," Rosello complained. While he conceded that the plan will generate savings, Rosello said that the "money will be available to bondholders, but to the detriment of the most vulnerable of our people. This is simply unfair."

One key institution targeted in the junta's austerity drive is the University of Puerto Rico (UPR), an island-wide, 11-campus system with nearly 60,000 students. The FOMB's plan for the university will cut its allocation of government funding by $\$ 211$ million, about a third of its budget. The system will be consolidated into fewer campuses, tuition doubled, fees increased, and student enrollment cut. The teaching staff will be reduced as well.

These cuts will gut the university system, erode its ability to conduct research, and result in fewer graduates prepared to teach in the public schools 
and work in government agencies or business management. By doubling tuition, the junta will radically diminish the university's capacity to continue serving as one of the key channels of upward social mobility for Puerto Rico's poor.

The assault on the university system offers an insight into the FOMB's plans for Puerto Rico's economy, particularly its human capital needs. UPR educates the vast majority of the island's publicsector employees, including health professionals. The FOMB envisions a streamlined or "right-sized" state that will provide fewer public services, an economy in which public corporations are dismantled or privatized, and a low-wage private sector that will need far fewer educated workers for management positions.

Three successive governments have reduced public-sector employment and reformed labor laws to decrease wages and weaken job protections. Even under the best-case scenario, Puerto Rico will experience negative growth for at least several more years, so employment prospects for educated workers are dim.

The situation for Puerto Ricans will deteriorate further when federal transfers are reduced in five years and hurricane-related funding is exhausted. The austerity measures will lead to further emi-
The idea that Puerto Ricans

are a divided nation has been debunked. ment that implements them will lose legitimacy and popular support.

\section{EXODUS}

Hurricane Maria accelerated the exodus of Puerto Ricans that began in 2004 when the economy started to contract and the government began dismissing thousands of public-sector employees. After 2010, as the US economy recovered from the Great Recession, out-migration intensified. Economic and social conditions had become unbearable for many Puerto Ricans mired in joblessness and poverty, with a dilapidated infrastructure and rapidly deteriorating public health-care and school systems. In April 2010, the official unemployment rate was just shy of 17 percent, and almost half the population was living in poverty.

During the past decade and a half, the numbers of Puerto Ricans migrating to the United States exceeded the numbers that left during the "Great Migration" of the 1950s. The Pew Foundation has reported that between 2005 and 2015, about 446,000 Puerto Ricans migrated to the mainland. By 2015, the population had declined by more than 10 percent from its peak of 3.8 million in 2004 .

An estimated 130,000 people, almost 4 percent of the population, migrated to the gration of the most skilled and valued workers.

The FOMB is restructuring capitalist development in the colony as it conducts an experiment in social engineering. Whatever economic model lies in Puerto Rico's future, it will be based on extracting more value from a vulnerable labor force. Acting as the federal government's fiscal enforcement agent, the junta's task is to create a new technocratic state that will ensure Puerto Rico subsidizes its continued colonial subordination. The costs of maintaining the colony must be borne by its inhabitants.

Although many economists argue that the FOMB's fiscal plan will not generate economic growth for some time, it is virtually certain that it will remain in place until a settlement has been reached with the hedge funds and institutional investors that hold most of Puerto Rico's debt. But forcibly aligning the labor market to the needs of US business interests, as the government reduces vital public services, is politically risky and can generate resistance. The proposed changes are so drastic that any democratically elected govern- mainland between July 2017 and July 2018, with the largest numbers leaving in the aftermath of Hurricane Maria. The Center for Puerto Rican Studies estimates that between 2017 and 2019, Puerto Rico may lose 14 percent of its population, about 470,000 people.

For the first time in its history, Puerto Rico has been undergoing systemic depopulation. Currently, more Puerto Ricans live in the United States (5.4 million) than in Puerto Rico (3.2 million), and the growth of the US resident population will easily outpace that of the island. Puerto Ricans are leaving because they envision a dystopian future for their homeland.

The social and economic impact of the postMaria exodus on Puerto Rico's future economic growth will be serious. College-educated and skilled Puerto Ricans are leaving in unprecedented numbers. A rising death rate among an older age distribution together with a declining fertility rate will further shrink the population. There is little prospect for a sustainable economic recovery given the continued depletion of the island's hu- 
man capital: its teachers, doctors and health care professionals, engineers and technicians, and experienced managers.

The FOMB's policies further encourage outmigration. Many of the measures enacted by both the junta and the local government create oppressive labor-market conditions that will spur young people to leave the island. The huge contraction of the public-sector workforce has reduced employment opportunities. The attack on UPR and the public education system discourages young families from staying in Puerto Rico. In short, a ruthless austerity regime has been imposed to achieve fiscal solvency and to promote the migration of Puerto Ricans who will have no role in the restructured economy envisioned by the junta.

\section{TRANSNATIONAL ACTIVISM}

The Rosello administration was roundly criticized for failing to prepare for Hurricane Maria and for its incompetence in staging the emergency response. However, the strongest criticisms were directed at the Federal Emergency Management Administration (FEMA), which was excoriated for its handling of the crisis and held responsible for hundreds of deaths. Investigations conducted by the Government Accounting Office, FEMA itself, and independent agencies concluded that FEMA's response ranged from incompetent to negligent. (Trump was an exception, congratulating FEMA for doing "an unappreciated great job.")

By contrast, when Hurricane Harvey hit the Houston area a month before Maria struck Puerto Rico, FEMA had quickly deployed more personnel and allocated greater resources to Texas. Three months after Maria, the Inter-American Commission on Human Rights reported that it was "deeply dismayed by the United States' lack of response to effectively protect the human rights of the Puerto Rican people." When criticized for the federal government's bungled emergency relief effort, Trump blamed Puerto Ricans, tweeting: "They want everything to be done for them when it should be a community effort."

In fact, rather than waiting for government assistance, Puerto Ricans reacted quickly. Throughout the island, residents organized relief and recovery campaigns. They established self-managed Centros de Apoyo Mutuo (Mutual Aid Centers or
CAMs) that pooled resources and raised money to meet the urgent need for food, water, and medical supplies and for recovery and rebuilding. Faced with what organizers called "the collapse of the state and the abuses of FEMA in post-Maria Puerto Rico," they also set up "discussion spaces to generate critical thinking and the understanding that we are facing a political disaster that is even more dangerous than the natural disaster." Technologically savvy Puerto Ricans established the Red de Apoyo Mutuo (Network for Mutual Assistance) to serve as an independent platform for the CAMs and diaspora organizations to "communicate, collaborate, and coordinate their decentralized activities."

Puerto Ricans in the United States organized a nationwide emergency assistance campaign to help the people on the devastated island as soon as the hurricane struck. Community-based advocacy organizations raised substantial donations and collected vital supplies for shipment to the island. Puerto Ricans in the diaspora responded more immediately and effectively to the crisis than the federal government did.

This post-Maria community response has been groundbreaking in its scale and also because it was organized outside the spaces controlled by the local government and federal agencies operating in Puerto Rico. The unmediated and spontaneous engagement between Puerto Ricans on the mainland and on the island may also be a bellwether of a new form of anticolonial activism. The closer connection between the diaspora and the colony made possible by new social media technologies has transformed the scale and frequency of Puerto Rican transnational interaction.

\section{REIMAGINING THE FUTURE}

The flow of people, knowledge, and supplies managed by autonomous organizations was focused on hurricane-recovery efforts, but also offers a glimpse of a more sustainable and resilient Puerto Rico with diminished reliance on US capital and the federal government. This novel form of cultural politics is quickly dismantling the artificial divisions that historically have been manufactured by Puerto Rico's political leadership to segregate boricuas residing in the United States from those on the island.

The idea that Puerto Ricans are a divided nation, and that they constitute two linguistically and 
culturally separate peoples, was always questionable-but now it has been debunked. Nowhere is the fallacy of a divided nation more evident than in the way the diaspora community has embraced the hundreds of thousands of Puerto Ricans who have sought refuge and a new life in United States. Hurricane Maria revealed that Puerto Ricans in the colony and in the diaspora embrace a common national identity. Puerto Rican identity is defined by distinctive cultural and linguistic attributes and by the shared history of a colonized and racialized people.

However, the current crisis has generated unprecedented migration, a virtually complete collapse of the local economy, and harsh austerity measures that are creating a dystopian level of precarity not experienced since the 1930s. This has led to the realization that the viability of Puerto Rican society and its distinctive way of life is threatened. Growing numbers of Puerto Ricans in the diaspora and on the island believe that the old colonial arrangement is untenable. A new political arrangement with the United States is necessaryone that acknowledges Puerto Rican national identity as unbounded by geography.

But colonialism denies the residents of Puerto Rico the political means to redefine the terms of their association with the United States and shape the future of their island nation. The diaspora community, dispersed throughout the United
States, also lacks the political power to shift federal policy.

Puerto Ricans migrate between one identity as colonized subjects, with its embedded tropes of inferiority, and another racialized identity that is denigrated and marginalized in the American white-supremacist social order. One of the most persistent colonial representations of Puerto Ricans is that they are a "dependent people" incapable of surviving on their own. But instead of falling into hopelessness and fatalism in the days and months following Maria, Puerto Ricans displayed activism and resilience-refuting this degrading depiction.

Puerto Ricans on the island and in the diaspora are more skeptical now than ever about the statehood and commonwealth parties' fanciful claims that they alone can persuade the United States to ease its colonial control over Puerto Rico. If Washington chooses to revisit the long-standing colonial formula, it will do so for two reasons. First, Puerto Rico is inconsequential to American economic and geopolitical interests, and too costly to sustain. And second, popular activism, resistance, and self-sufficiency will permanently damage the credibility of the island's ideologically bankrupt political parties. Hurricane Maria exposed the failings of the current colonial system and has created new space for the people to reimagine Puerto Rico's political future. 